\title{
Chemical Composition of Wild-type and Mutant Aspergillus nidulans Cell Walls. The Nature of Polysaccharide and Melanin Constituents
}

\author{
By A. T. BULL* \\ Soil Microbiology Laboratory, Department of Agronomy, \\ Cornell University, Ithaca, New York I4850, U.S.A.
}

(Accepted for publication I8 June 1970)

\begin{abstract}
SUMMAR Y
Chitin and a $\beta$-linked glucan were the major chemical components of Aspergillus nidulans cell walls. Other monomeric residues identified in enzymic and acid hydrolyses of whole cell walls and cell-wall fractions included galactose, mannose, glucuronic acid and galactosamine. The $\beta$-glucan contained $(\mathrm{I} \rightarrow 3)$ and $(\mathrm{I} \rightarrow 6)$ linkages and was two-thirds digested by an exo- $\beta$-D-I, 3 glucanase prepared from a cell-wall lysing Streptomyces species. An $\alpha$-glucan was identified as a cell-wall component and it also contained $(\mathrm{I} \rightarrow 3)$ linkages. This latter polysaccharide was distinguishable from nigeran (an $\alpha-I, 3 ; \alpha-I, 4$ glucan present in other Aspergillus species) by infrared spectroscopy and by its low susceptibility to hydrolysis by an endo- $\alpha-\mathrm{I}, 3 ; \alpha-\mathrm{I}, 4$ glucan glucanohydrolase. Both glucans were alkali-soluble, but the $\beta$-glucan was completely solubilized only after acid extraction of the wall. The $N$-acetylglucosamine to galactosamine ratio in the $A$. nidulans cell wall was $\mathrm{I} \cdot 32$ and the two hexosamines were shown to be constituents of distinct polymers. The remaining cell wall was accounted for by protein, lipids, readily extractable and bound, and, in the wild-type, melanin.

The melanin was distributed throughout the cell wall but was associated particularly with the chitin fraction. The pigment has been partially characterized chemically and contains indolic residues; this result does not substantiate earlier views that indolic melanins are peculiar to the animal kingdom. Melanin appears to be a finite heteropolymer both in terms of its molecular size and its chemistry.
\end{abstract}

\section{INTRODUCTION}

A positive correlation has been demonstrated in several species between the presence of melanin, or melanin-like pigments, in the cell walls of fungi and resistance: to microbial and enzymatic lysis (Potgieter \& Alexander, I966; Bloomfield \& Alexander, 1967). Furthermore, studies on Aspergillus nidulans (Kuo \& Alexander, 1967) established that the resistance to lysis was affected by the melanin concentration in the cell wall. The mechanism by which melanin may exert its antilytic effect in this fungus has recently been discussed (Bull, I970a).

As an essential prelude to investigations of the melanin effect the cells walls of Aspergillus nidulans were examined chemically with reference to the nature of

* Permanent address: Department of Microbiology, Queen Elizabeth College (University of London), Campden Hill, London W.8. 
melanized and non-melanized walls. Extensive chemical analyses of cell walls of filamentous moulds remain few in comparison with bacteria and, in particular, only two fungal melanins have been studied in any detail (Nicolaus, Piattelli \& Fattorusso, 1964).

\section{METHODS}

Microbiological techniques. Wild-type strain 13 and an albino mutant I3. I. OL of Aspergillus nidulans Eidam (Wint.) have been described previously (Bull \& Faulkner, 1964, 1965). The two strains were distinguished by the presence and absence respectively of melanin in their cell walls. Stock cultures were maintained on a glucose-salts agar medium and ro 1 . batch cultures for cell-wall preparation were grown in a liquid medium of similar composition (Carter \& Bull, 1969; Bull, 1970a).

Cell walls of Aspergillus nidulans I3. I. OL were degraded extensively by a complex of lytic enzymes synthesized by a Streptomyces species. The lytic organism was isolated from soil enriched with Phytophthora megasterium mycelium (Wang, 1964). Cultures of the streptomycete were maintained on a mineral salts agar containing $2 \%$ (w/v) wet wt of blended Aspergillus oryzae mycelium (supplied by Wallerstein Co., Division of Travenal Laboratories Inc., Staten Island, New York, U.S.A.) as the sole carbon source. Forty-litre cultures of the streptomycete were grown in a stainlesssteel fermenter and the lytic enzymes were precipitated from the culture liquors by $70 \%$ saturation with $\left(\mathrm{NH}_{4}\right)_{2} \mathrm{SO}_{4}$. Full details of these procedures, together with descriptions of $\beta$-I,3 glucanase and chitinase purification, have been reported previously (Bull, I970a).

Cell-wall preparation. Two methods of cell-wall preparation were used. (i) Freshly harvested mycelium was washed thrice with $\mathrm{Na} / \mathrm{K}$ phosphate buffer $(0 \cdot 033 \mathrm{M}, \mathrm{pH} 6 \cdot \mathrm{I})$, its $\mathrm{pH}$ adjusted to $6 \cdot 8$ with $2 \mathrm{~N}-\mathrm{NaOH}$ and collected by centrifugation. The mycelium was blended for 2 min. in an Omni-Mixer (Ivan Sorvall Inc., Norwalk, Connecticut, U.S.A.), then treated with $1 \%(\mathrm{w} / \mathrm{v})$ sodium dodecyl sulphate (Io $\mathrm{ml} . / \mathrm{g}$. wet wt mycelium) (Mahadevan \& Tatum, 1965) and stirred overnight at $4^{\circ}$. Fivefold washing of the hyphal fragments in phosphate buffer was followed by treatment of the residue with increasing concentrations of aqueous ethanol, after which it was suspended in distilled water and freeze-dried. (ii) Phosphate-buffer washed mycelium (I.5 g. amounts in $50 \mathrm{ml}$. buffer) was macerated in a glass tissue homogenizer (Thomas, Philadelphia, Pennsylvania, U.S.A.) driven by an electric motor at maximum speed and then centrifuged at $800 \mathrm{~g}$ for Io min. Merthiolate $(0.0 \mathrm{I} \% \mathrm{v} / \mathrm{v})$ (Eli Lilly and Co., Indianapolis, Indiana, U.S.A.) was added to the buffer solution to prevent microbial growth. The supernatant containing cytoplasmic debris was discarded and the combined residues resuspended in buffer $\left(50 \mathrm{ml}\right.$.). The suspension held below $12^{\circ}$ was ultrasonicated in $15 \mathrm{ml}$. amounts for $2 \mathrm{~min}$. with the sonicator (Biosonik, Bronwill, Rochester, New York, U.S.A.) operating at full power. Cell-wall material was recovered by centrifugation $(800 \mathrm{~g}$, for $\mathrm{I} O \mathrm{~min}$.) and the ultrasonication cycle repeated twice more. The residue, collected at $1400 \mathrm{~g}$ for Io $\mathrm{min}$., was washed twice with chilled buffer and freeze-dried. Wall preparations were examined microscopically during the course of their isolation; the procedures detailed above removed all cytoplasmic material as shown by staining techniques, phase-contrast observation and lack of detectable extinctions at 260 and $280 \mathrm{~nm}$.

Chemical analyses. Chemical fractionation of the cell wall was made according 
to the method described by Mahadevan \& Tatum (1965). At all times during the fractionation, reaction mixtures were flushed with nitrogen gas to minimize oxidative degradation. The four fractions were characterized as follows: (I) alkali-soluble; (2) acid-soluble; (3) acid-insoluble, alkali-soluble; (4) acid- and alkali-insoluble. Fractions I, 3 and 4 were suspended in distilled water, neutralized, then dialysed against distilled water for $36 \mathrm{~h}$. and freeze-dried; fraction 2 was neutralized with solid $\mathrm{Ba}(\mathrm{OH})_{2}$ and the supernatant, after centrifugation, was freeze-dried.

In some experiments cell-wall fractions were extracted with Schweizer's cuprammonium reagent, $13.5 \mathrm{~g}$. Cu/l. (Jayme \& Lang, 1963). The sample (30 mg.) was twice extracted with the solvent $\left(5 \mathrm{ml}\right.$.) under $\mathrm{N}_{2}$ for $3 \mathrm{~h}$. at room temperature. The residue was centrifuged off (I4,000 $\mathrm{g}$, I5 $\mathrm{min}$.), washed exhaustively with distilled water and dried over $\mathrm{NaOH}$ pellets.

Carbon, hydrogen and nitrogen determinations were made with a model $185 \mathrm{C}-\mathrm{H}-\mathrm{N}$ Analyser (Hewlett-Packard, Avondale, Pennsylvania, U.S.A.) using 2, 32 and 8 attenuation respectively for $\mathrm{N}_{2}, \mathrm{CO}_{2}$ and $\mathrm{H}_{2} \mathrm{O}$. The instrument was calibrated with cyclohexane-2,4-dinitrophenyl hydrazone $(\mathrm{N}=20.14 \%)$ and acetanilide $(\mathrm{N}=10.36 \%$ ). Micro-Kjeldahl determinations of total $\mathrm{N}$ were made by the method of Bremner (1960). Phosphorus was determined with the $N$-phenyl-p-phenylenediamine hydrochloride chromogen (Dryer, Tammes \& Roth, 1957).

Acid hydrolyses of cell walls were made by the procedures described by BartnickiGarcia (1966) and were carried out under $\mathrm{N}_{2}$. After hydrolysis with $\mathrm{H}_{2} \mathrm{SO}_{4}$, hydrolysates were neutralized with $\mathrm{BaCO}_{3}$ and the clarified supernatants deionized by passage through a bed of Dowex-50W-X 8 (hydrogen form). Hydrochloric acid was removed by evaporation in vacuo over $\mathrm{NaOH}$ pellets. Cell walls were enzymically dissolved with a partially purified lytic complex (Bull, I970a) in 0.05M-citrate-phosphate buffer, $\mathrm{pH} 5.0$, containing $0.01 \%(\mathrm{w} / \mathrm{v})$ merthiolate. Reaction mixtures contained 353 units of endo- $\beta-\mathrm{I}, 3$ glucanase $(\beta-1,3(4)$ glucan glucanohydrolase, E.C. 3.2.I.6), 2.62 units of chitinase (chitin glycanohydrolase, E.C. 3.2.I.14), 93 units of mycodextranase $(\alpha-I, 3, \alpha-I, 4$ glucan glucanohydrolase), and unspecified lipolytic and proteolytic activities. Highly purified hydrolases (Bull, I970a) also were used to investigate the nature of various cell-wall polymers.

Cell-wall hydrolysis products were separated by descending paper chromatography (Whatman no. I) or ascending cellulose thin-layer chromatography (Cellulose $\mathrm{F}$, E. Merck AG, Darmstadt, Germany). Chromatograms were irrigated with either butan-I-ol + pyridine + water $(6+4+3, v / v)$ or propan-2-ol+acetic acid + water $(3+0.5+\mathrm{I}, \mathrm{v} / \mathrm{v})$ and developed with aniline hydrogen phthalate, ammoniacal $\mathrm{AgNO}_{3}$ (reducing sugars), $p$-dimethylaminobenzaldehyde (amino sugars) or ninhydrin. (amino acids). Sugars separated on paper chromatograms were estimated quantitatively by cutting out the sugar spots (located on parallel chromatograms developed with. $\mathrm{AgNO}_{3}$ ), eluting with distilled water and determining the sugar concentration of the clarified eluate with anthrone and $p$-dimethylaminobenzaldehyde.

Total carbohydrate was determined by the anthrone procedure of Loewus (I952) using a glucose standard. Reducing sugars were determined as glucose with a lowalkaline $\mathrm{Cu}$ reagent (Somogyi, I952) and the arsenomolybdate chromagen of Nelson (1944). The method of Reissig, Strominger \& Leloir (1955) was used to determine: $N$-acetylamino sugars which were expressed as $N$-acetylglucosamine. Glucose and galactose were assayed enzymically with the appropriate sugar oxidases (Glucostat 
Special and Galactostat, Worthington Biochemical Corp., Freehold, New Jersey, U.S.A.). Galactosamine identity was confirmed by converting it to the corresponding pentose, i.e. lyxose (Stoffyn \& Jeanloz, I954). Presumed galactosamine spots were cut out from paper chromatograms and eluted with water. The clarified eluate was spotted $(20 \mu \mathrm{l}$.) on to cellulose TLC plates which, after drying, were sprayed with $2 \%(\mathrm{w} / \mathrm{v})$ ninhydrin containing $4 \%(\mathrm{v} / \mathrm{v})$ pyridine and heated to $80^{\circ}$ for $3 \mathrm{~h}$. in an atmosphere of pyridine and water $(\mathrm{I}+\mathrm{I})$. The dried plates were irrigated with butan-I-ol + ethanol + water $(4+I+I, v / v)$ and galactosamine, glucosamine, lyxose and arabinose co-chromatographed for reference. Uronic acids were determined with the Dische carbazole reagent (Gancedo, Gancedo \& Asensio, 1968). Passage of hydrolysates through a bed of Amberlite IR-4 B removed the mineral acid following which the uronic acids specifically were absorbed on to Dowex-I (formate form) and recovered by elution with $0.5 \mathrm{~N}$-formic acid. Protein and lipid contents were determined on cell-wall material prepared by method (ii) above. Protein was measured directly in untreated walls using the Folin-Ciocalteu reagent (Lowry, Rosebrough, Farr \& Randall, I95I), or in detergent extracts of cell walls (van Soest, I963). Readily extractable and bound cell-wall lipids were measured by the procedure of BartnickiGarcia \& Nickerson (1962). Nucleic acid content was estimated by measuring the extinction at $260 \mathrm{~nm}$. of hydrochloric acid digests of cell walls; absorption readings were corrected for background. Ultraviolet and visible spectra were obtained with a Beckman DB-G Spectrophotometer (Beckman Instruments Inc., Fullerton, California, U.S.A.). Samples for infrared spectroscopy were powdered with i.r. quality potassium bromide, pressed under vacuum into discs, and the spectra recorded in a Beckman IR Io infrared spectrophotometer.

Melanin investigations. Melanin was extracted from wild-type mycelia by the procedures described by Nicolaus et al. (I964). The fine amorphous black pigment could be solubilized completely at $60^{\circ}$ by $0.5 \mathrm{~N}-\mathrm{NaOH}$. Melanin was determined gravimetrically or by measuring the extinction at $540 \mathrm{~nm}$. of $\mathrm{NaOH}$ solutions. The molecular-size distribution of melanin samples was investigated by gel filtration on a column $(255 \times 20 \mathrm{~nm}$.) of Sephadex G-200 (Pharmacia, Uppsala, Sweden). Samples were applied to the column and eluted with I $\mathrm{M}-\mathrm{NaCl}$. The column was calibrated with the following proteins of known molecular weight: urease $\left(4.8 \times 10^{5}\right), \beta$-glucuronidase $\left(2.8 \times 10^{5}\right)$, phospholipase $\left(\mathrm{I} \cdot 0 \times 10^{5}\right)$ and ribonuclease $\left(\mathrm{I} \cdot 4 \times 10^{4}\right)$. Nitrogen was determined by the methods noted above. The preparation of $\left[{ }^{14} \mathrm{C}\right]$ melanin specimens, specifications of radiochemicals, counting procedures and equipment have been reported previously (Bull, I968). Attempts to characterize the melanin in terms of its degradation products (Nicolaus et al. 1964) were made by (I) fusing in a mixture of sodium hydroxide and sodium dithionate at $300^{\circ}$, and (2) oxidizing with $3 \%(\mathrm{w} / \mathrm{v})$ aqueous potassium permanganate. Chemisynthetic DOPA-melanin was prepared by the method described by Bull (I970 $b$ ).

Materials. Insoluble laminaran was obtained from the Seaweed Research Institute, Musselburgh, Midlothian, Scotland; nigeran extracted from Aspergillus japonicus QM 332 and A. luchuensis QM 873 were gifts from D. E. Eveleigh of the Prairie Regional Laboratory, Saskatoon, Saskatchewan, Canada; chitin was prepared as a colloidal suspension from crustacean chitin (Kylan PC, Moretex Chemical Products, Spartanburg, South Carolina, U.S.A.). Ion exchange resins were purchased from J. T. Baker Chemical Co. (Phillipsburg, New Jersey, U.S.A.) and enzymes from Worthington 
Biochemical Corp. A wide range of non-substituted and substituted indoles, catechols, pyrroles and benzoic acids were purchased from Aldrich Chemical Co. Inc., Milwaukee, Wisconsin, U.S.A.; Eastman Organic Chemicals, Rochester, New York, U.S.A.; and K. and K. Laboratories Inc., Plainview, New York, U.S.A.

\section{RESULTS}

The growth characteristics of Aspergillus nidulans wild-type and albino strains in 10 1. batch cultures were similar to those reported by Carter \& Bull (I969). Both strains produced homogeneous, filamentous growth; pellet formation did not occur and only during the late stages of autolysis were abnormal cell morphologies observed. At a growth temperature of $32^{\circ}$, the maximum mycelial dry weight was produced after about $35 \mathrm{~h}$. $\left(Y_{\text {glucose }}=0.40\right.$ to $0.44 \mathrm{~g}$. dry wt g. $\left.{ }^{-1}\right)$. Intracellular melanin synthesis became noticeable after about $40 \mathrm{~h}$., by which time the medium was exhausted of glucose. A few hours later the culture began to autolyse and the $\mathrm{pH}$ value progressively rose, accompanied by an accumulation of melanin in the medium. Cultures for cell-wall studies were harvested during the maximum population phase (strain 13. I.OL) or, when melanized material was required, after $25 \%$ autolysis had occurred (strain I3). The cell walls of both strains comprised $18 \%$ of the total dry weight of washed mycelia under these conditions.

\section{Chemistry of wild-type and mutant cell walls}

The basic chemical features of the cell walls of the wild-type and albino mutants are shown in Table I. Elemental analyses suggested identical chemical composition of the two cell walls prior to the establishment of secondary metabolism and the subsequent large-scale synthesis of melanin. Control analyses made on cell walls of Aspergillus oryzae $(\mathrm{N}=3.5 ; \mathrm{P}=\mathrm{I} \cdot 0 \%)$ and Neurospora crassa $(\mathrm{N}=2.9 \% ; \mathrm{P}=0.7 \%)$ gave results of the same order as the $A$. nidulans data and agreed well with previously reported values (e.g. Mahadevan \& Tatum, 1965). Because melanin interfered with the assaying of cell-wall components, analyses of certain components were made on the albino cell walls only.

Neutral sugars. Acid hydrolysates $\left(22 \cdot 5 \mathrm{~N}-\mathrm{H}_{2} \mathrm{SO}_{4}\right.$ for 3 h. at $30^{\circ}$; dilution to $0.85 \mathrm{~N}$ and $4 \mathrm{~h}$. at $97^{\circ}$ ) of both cell walls contained three neutral monosaccharides, glucose, galactose and mannose. The amounts in the cell wall of Aspergillus nidulans I 3. I. OL were determined enzymically and by quantitative paper chromatography of acid hydrolysates (Table 2). The glucose content was considerably underestimated. Paper chromatograms of wall digests contained several reducing sugar spots (equivalent to I $8.7 \%$ of the total carbohydrate) which were identified, tentatively, as $\beta$-linked (Bull, 1962) and $\alpha$-linked (see below) glucose oligosaccharides. The two assays of galactose agreed very closely and, because all of this monosaccharide was a substrate for galactose oxidase, a D-configuration was concluded.

Amino sugars. Three amino sugars, having $R_{\mathrm{Gle}}$ values of $0.60,0.72$ and $\mathrm{I} .25$ in the butan-I-ol + pyridine + water solvent, were detected in the acid hydrolysates $\left(6 \mathrm{~N}-\mathrm{HCl}\right.$ for $6 \mathrm{~h}$. at $\left.100^{\circ}\right)$ of the mutant cell walls. The two most rapidly moving sugars had $R_{\text {Glc }}$ values identical with those of authentic glucosamine and $N$-acetylglucosamine. The unknown component $\left(R_{\mathrm{Glc}} 0.60\right)$ had a mobility close to that reported for galactosamine. The identity of the non-acetylated hexosamines was 
confirmed by their oxidation to pentoses; only arabinose and lyxose were detected as products from presumed glucosamine and galactosamine respectively. Glucosamine, $\mathrm{N}$-acetylglucosamine and galactosamine were present in the cell-wall hydrolysate in the ratio $5 \cdot 2: 1: 4 \cdot 7$ (see Table 2 ).

Uronic Acids. The cell walls of the wild type and the mutant contained significant amounts of a hexuronic acid residue (Table I) identified on the basis of paper chromatography as glucuronic acid. The most reliable estimates of glucuronic acid were

Table I. Chemical composition of the cell walls of Aspergillus nidulans

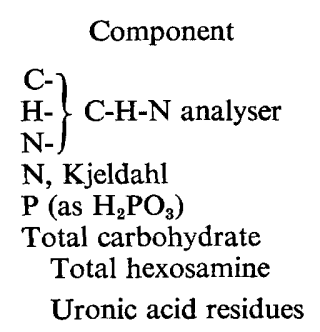

Protein

Nucleic acid

Lipid

Free

Bound

Melanin

Total

'Encrusting'

Sum ${ }^{* *}$

Percentage of the cell wall dry weight

\begin{tabular}{|c|c|}
\hline Wild type, 13 & Mutant, I3. I.OL \\
\hline $\begin{array}{c}27.6(45 \cdot 5)^{*} \\
4.8(7 \cdot 7)^{*}\end{array}$ & $\begin{array}{r}41 \cdot 4 \\
6 \cdot 7\end{array}$ \\
\hline $4 \cdot \mathrm{I}(3 \cdot 4)^{*}$ & $3 \cdot 3$ \\
\hline $\begin{array}{l}3.7 \\
0.82\end{array}$ & $\begin{array}{l}3 \cdot 0 \\
0.86\end{array}$ \\
\hline $60 \cdot 5$ & $82 \cdot 8$ \\
\hline n.d. & $25 \cdot 1$ \\
\hline $\begin{array}{l}\mathbf{I} \cdot 9 \dagger \\
\mathrm{r} \cdot 0 \dagger\end{array}$ & $\begin{array}{l}3.5 \dagger \\
2.6 \ddagger\end{array}$ \\
\hline $\begin{array}{l}5 \cdot 0 \S \\
10 \cdot 0-10 \cdot 4 \| \\
8 \cdot 9-12 \cdot 7 \emptyset\end{array}$ & $\begin{array}{l}8 \cdot 0 \S \\
8 \cdot 6-10 \cdot 6 \| \\
8 \cdot 9-9 \cdot 4 \|\end{array}$ \\
\hline $0.6 \mathrm{I}$ & 0.60 \\
\hline $2 \cdot 3$ & $2 \cdot 8$ \\
\hline $7 \cdot 2$ & $6 \cdot 2$ \\
\hline $16 \cdot 3-18 \cdot 2$ & 0 \\
\hline $1 \cdot 0-3 \cdot 2$ & o \\
\hline $9 \mathrm{I} \cdot 5-\mathrm{IOI} \cdot \mathrm{I}$ & IOI $\cdot \mathrm{I}-\mathrm{IO} 2 \cdot 7$ \\
\hline
\end{tabular}

n.d. $=$ not determined.

* Values refer to pre-melanized cell walls.

$\uparrow$ Values derived from paper chromatographically separated material.

\$ Method of Gancedo et al. (1968).

$\S$ Method of Lowry et al. (I95I).

|| Detergent-extracted cell walls.

If Values calculated from total nitrogen data and corrected for total hexosamine and melanin contents of the samples.

** Total carbohydrate, protein, lipid, nucleic acid and melanin.

Table 2. The neutral and amino sugars present in the cell wall of Aspergillus nidulans 13.I.OL

\begin{tabular}{|c|c|}
\hline Sugar & $\begin{array}{c}\text { Percentage of cell wal } \\
\text { dry weight }\end{array}$ \\
\hline $\begin{array}{l}\text { Glucose } \\
\text { Galactose } \\
\text { Mannose }\end{array}$ & $\begin{aligned} & 28 \cdot 9 ; 26 \cdot 2^{*} \\
& 3 \cdot 8 ; 3 \cdot 9^{*} \\
& 2 \cdot 8\end{aligned}$ \\
\hline $\begin{array}{l}\text { Glucosamine } \\
N \text {-Acetylglucosamine } \\
\text { Galactosamine }\end{array}$ & $\left.\begin{array}{c}12 \cdot 0 \\
2 \cdot 3 \\
10 \cdot 8\end{array}\right\} 14 \cdot 3$ \\
\hline
\end{tabular}

Sugars determined by quantitative paper chromatography.

* Sugars determined enzymically. 
obtained by using the method of Gancedo et al. (I968), which gave values $47 \%$ (wild-type) and $25 \%$ (mutant) less than those obtained by applying the carbazole assay directly to $\mathrm{H}_{2} \mathrm{SO}_{4}$ hydrolysates. The hexuronic acid contents of Aspergillus oryzae and Neurospora crassa cell walls were found to be $2.7 \%$ and $3.4 \%$ respectively when estimated by the latter method.

Table 3. Infrared spectroscopy of purified cell walls: distinctive band assignments

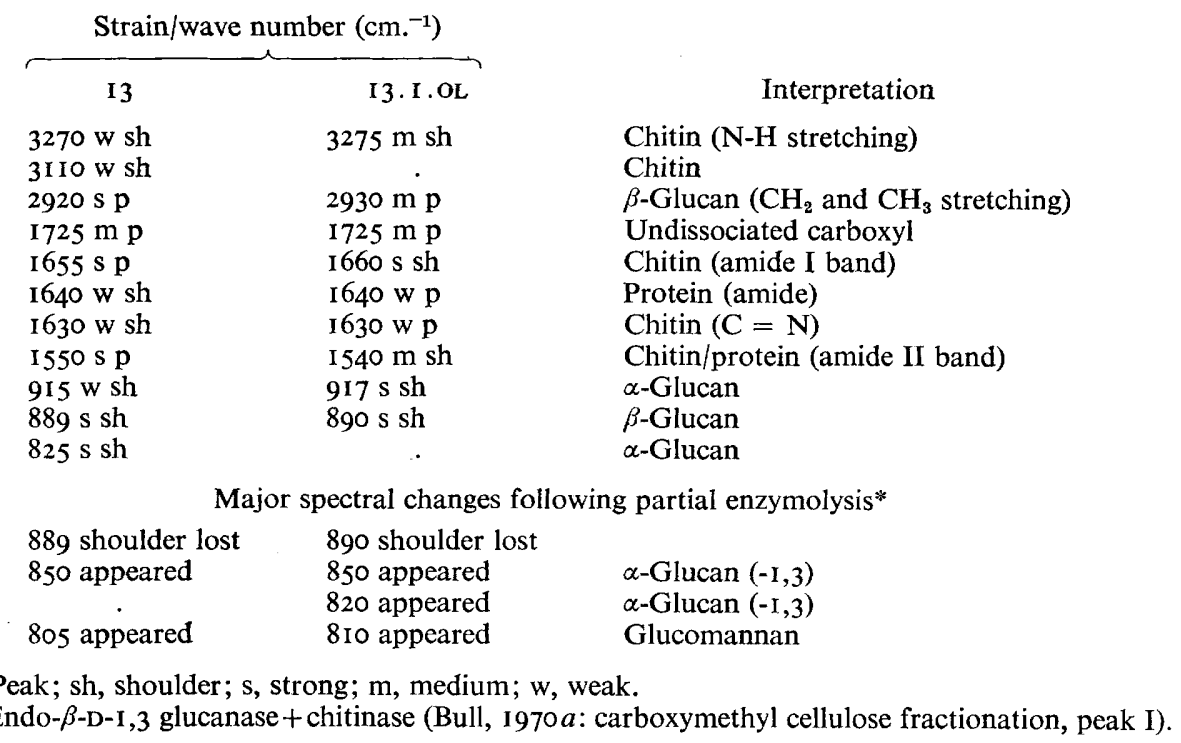

Protein. The cell walls of the wild-type and mutant Aspergillus nidulans were similar in containing approximately $10 \%$ of protein. Table $\mathrm{I}$ indicates efficiency of detergent extraction in the determination of cell-wall protein. Cell walls were extracted $(\times 6)$ with anionic or cationic detergents and the amount of protein recovered agreed well with that calculated on the basis of total nitrogen.

Lipid. The contents of readily extractable and bound lipids in the two cell walls were not significantly different (Table I).

Nucleic acid. Absorption spectra of cell-wall hydrolysates $\left(6 \mathrm{~N}-\mathrm{HCl}\right.$ for $8 \mathrm{~h}$. at $\left.100^{\circ}\right)$ indicated the presence of nucleic acid bases. Using a molar extinction of 8800 for an equimolar mixture of adenine, cytosine, guanine and uracil (summed molecular weight, 509), the nucleic acid content (as RNA) of the cell walls was calculated to be less than $\mathrm{I} \%$ of the dry weight (Table I). Exhaustive washing of the cell-wall. preparations with phosphate buffer or partial destruction with crude Streptomyces lytic enzymes failed to remove this nucleic acid component.

Melanin. The melanin content of wild-type Aspergillus nidulans was found to account for between 16.3 and $18.2 \%$ of the cell wall on a dry weight basis. Of this melanin, a small proportion could be released from the cell wall by ultrasonication in the presence of detergents (Table I) (Bull, 1970a).

Infrared spectroscopy. The salient absorption maxima in the i.r. spectra of wild-type and mutant Aspergillus nidulans cell walls are summarized in Table 3. Reference spectra were recorded also of representative $\beta$-glucans (laminaran, cellulose, pustulan), 
$\alpha$-glucans (nigeran, dextrin) and other polymers of relevance to the chemistry of fungal cell walls (yeast mannan, galactan, native and chemisynthesized melanins). Bands were assigned after comparisons of the cell wall and reference spectra and reference to appropriate literature data (Bacon, Jones, Farmer \& Webley, I968; Barker, Bourne, Stacey \& Whiffen, I954; Pearson, Marchessault \& Liang, 1960; Marchessault, 1962; Mitchell \& Scurfield, 1967). Infrared analyses indicated the presence of $\alpha$ (915 and $\left.825 \mathrm{~cm}^{-1}\right)$ and $\beta-\left(890 \mathrm{~cm}^{-1}\right)$ linked glucans, chitin $(3270,1665,1630$ and $1550 \mathrm{~cm} .{ }^{-1}$ ) and protein (I 640 and $1550 \mathrm{~cm}^{-1}$ ) in the cell walls of both strains. The $1550 \mathrm{~cm} .^{-1}$ absorbance can be assigned to amide groups which could have arisen from protein and chitin. Similarly, the undissociated carboxyl absorbance at $1725 \mathrm{~cm} .^{-1}$ may have comprised both protein and melanin signals. The presence of melanin in the cell wall of the wild-type strain was not indicated by i.r. spectroscopy. Partial degradation of the cell walls by a mixture of endo- $\beta-D-1,3$ glucanase and chitinase caused the $890 \mathrm{~cm} .^{-1}$ absorbance to be lost while absorbance maxima characteristic of $\alpha$-glucans ( 840 and $820 \mathrm{~cm}^{-1}$ ) became discernible (Table 3). A shoulder at 805 to $8 \mathrm{IO} \mathrm{cm}^{-1}$ also was indicated after partial hydrolysis, a feature suggestive of a glucomannan component (Marchessault, 1962).

\section{Chemical fractionation of the cell wall}

The cell wall was extracted chemically with alkali and mineral acid in order to obtain information on the nature of the polymeric components. Such attempts at fractionation can resolve the polymers only partially, but use of the Mahadevan \& Tatum protocol (Mahadevan \& Tatum, 1965) with the Aspergillus nidulans cell wall enabled at least two polymers to be isolated and identified. Cell walls of the albino mutant or premelanized wild type were used to avoid complications due to melanin which is extracted by the alkali treatments.

Fraction I. Cell walls (500 mg.) prepared from Aspergillus nidulans 13. I.OL were extracted with $2 \mathrm{M}-\mathrm{NaOH}(250 \mathrm{ml}$.) at room temperature for $\mathrm{I} 6 \mathrm{~h}$. The $24 \%$ of the total wall material recovered by this treatment was largely insoluble in cold water, and the only identifiable soluble components were glucose and reducing sugars with $R_{\text {Glc }}$ values referable to laminaridextrins (Bull, 1962). Elemental analysis of fraction I gave $\mathrm{C}=35.8 \%, \mathrm{H}=6.30 \%, \mathrm{~N}=0.31 \%$ and $\mathrm{P}=\mathrm{I} \cdot \mathrm{II} \%$. The $\mathrm{P}$ content represented approximately one-third of the total wall content. Acid hydrolysis produced glucose $(62.5 \%)$, galactose $(4.7 \%)$ and galactosamine. The latter was not estimated quantitatively, but paper chromatographic evidence suggested that the majority of the galactosamine was present in this fraction (see fraction 2 below). Fraction I material was not very susceptible to $\beta$-I,3 glucanase attack and only $7 \%$ of the material was solubilized (based on glucose and laminaritetraose recovery).

Infrared spectra of fraction I showed a strong shoulder at 917 to $915 \mathrm{~cm} .^{-1}$, weak shoulders at $890 \mathrm{~cm}^{-1}$ and $800 \mathrm{~cm} .{ }^{-1}$, and a medium peak at 830 to $825 \mathrm{~cm}^{-1}$. These absorbances are indicative of an $\alpha$-glucan containing $-\mathrm{I}, 3$ glucosidic linkages and a small amount of a $\beta$-linked glucan. The absorbance at $800 \mathrm{~cm} \cdot .^{-1}$ could have been due to the $\alpha-\mathrm{I}, 3$ glucan or could have arisen from a glucomannan. Treatment of fraction I with $\beta-\mathrm{I}, 3$ glucanase produced sharper definition of the 920 to $910 \mathrm{~cm}^{-1}$ shoulder and resolved the 830 to $825 \mathrm{~cm}^{-1}$ absorbance into two small peaks $(850$ and $835 \mathrm{~cm} \cdot{ }^{-1}$ ), which pointed to the $\alpha$-glucan being of the $\alpha-1,3$ type described by Bacon et al. (1968) and not of the nigeran (Glcp $\alpha \mathrm{I}-4 \mathrm{Glc}$; Glcp $\alpha \mathrm{I}-3 \mathrm{Glc}$ ) type (see 
Fig. I). Figure I shows also that $\mathrm{NaOH}(3 \%$,w/v) extractions of the cell wall for $5 \mathrm{~h}$. at high temperature $\left(75^{\circ}\right.$ ) produced still greater resolution of the $\alpha-\mathrm{I}, 3$ glucan absorbance peaks and gave further evidence of mannose-containing polysaccharides $\left(870 \mathrm{~cm} .^{-1}\right.$ absorbance). When fraction I was incubated with a mycodextranase-containing preparation (Bull, 1970a), reducing sugars other than glucose and $\beta$-oligoglucosides were released. A preparation having $2 \cdot$ I units of mycodextranase produced $62.0 \%$

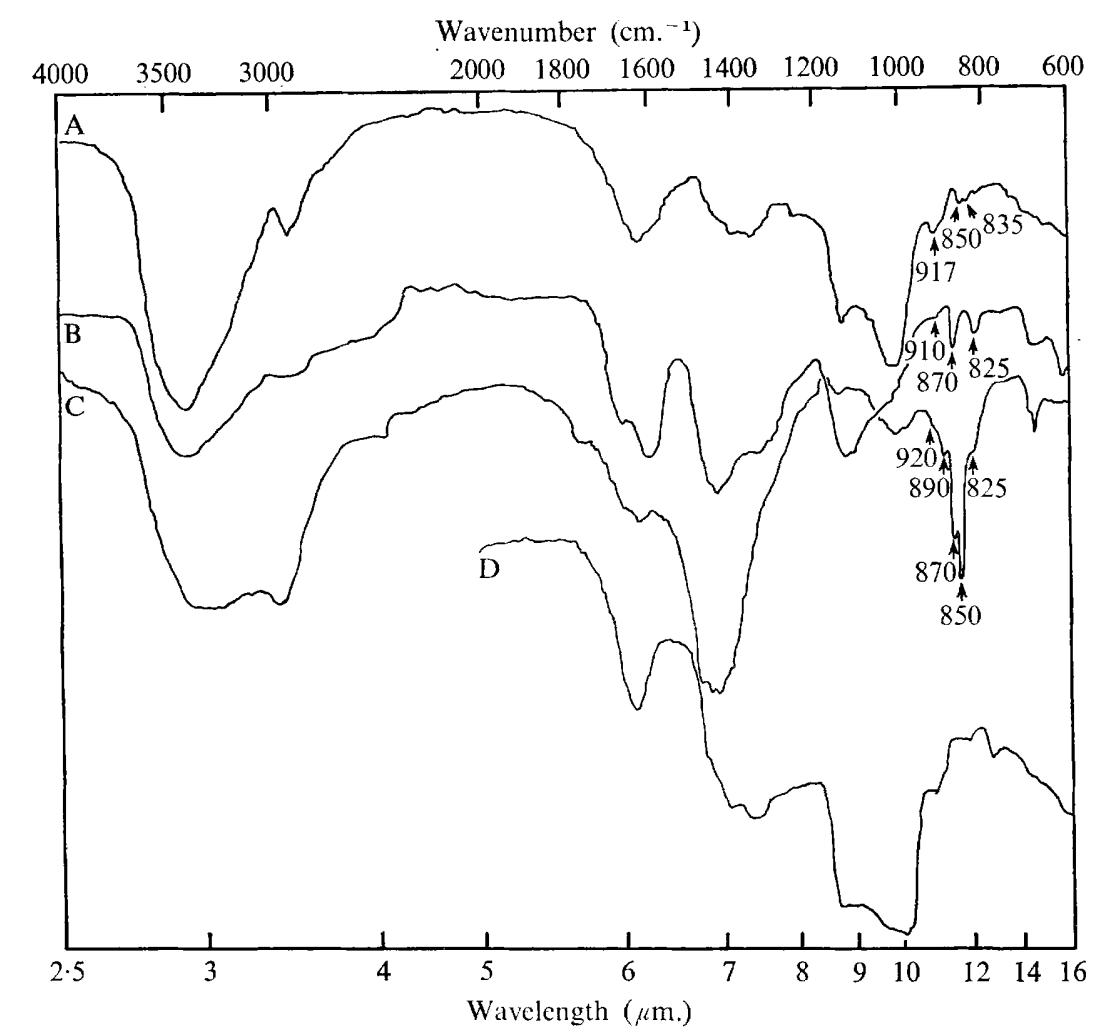

Fig. I. Infrared spectra of Aspergillus nidulans cell walls: $\alpha$-glucans. A, Cell-wall fraction I after treatment with $\beta$-D-I,3 glucanase. B, Cell-wall fraction 2. C, Hot alkali extract of the cell wall (see Results section for further experimental details). D, Nigeran (ex Aspergillus japonicus QM 332). Tracings displaced vertically to facilitate comparison.

hydrolysis of the nigeran samples and $13.5 \%$ of fraction 1 . Two $\alpha$-linked oligoglucosides detected in nigeran digests were identified as nigerose (Glcp $\alpha \mathrm{I}-3 \mathrm{Glc}$ ) and a tetrasaccharide (Glcp $\alpha \mathrm{I}-3 \mathrm{Glc} p \alpha \mathrm{I}-4 \mathrm{Glc} p \alpha-3 \mathrm{Glc}$ ) (chromatographic criteria of Tung \& Nordin, 1967). Unequivocal proof of the presence of these sugars in fraction I digests was not obtained. Following $\beta$-I, 3 glucanase digestion of fraction $\mathrm{I}$, the absorbance characteristic of the $\beta$-glucan was lost and consequently the latter contained some $-\mathrm{r}, 3$ linked residues; simultaneously, the $800 \mathrm{~cm} .^{-1}$ absorbance shifted to 810 to $800 \mathrm{~cm}^{-1}$ which was preliminary evidence of a glucomannan entity in the fraction. The effect of Schweizer's reagent on the i.r. spectrum of fraction I was slight; most significant was the retention of the absorbances at 917 and $890 \mathrm{~cm}^{-\mathbf{1}}$. Spectroscopic analyses of the corresponding cell-wall fraction from Aspergillus oryzae 
and Neurospora crassa gave evidence of $\alpha$ - and $\beta$-glucans and the $N$. crassa spectrum also had a weak absorbance at $770 \mathrm{~cm} .^{-1}$, which was suggestive of a galactan.

Fraction 2. The residue from cold alkali treatment was extracted with hot $\mathrm{H}_{2} \mathrm{SO}_{4}$ $\left(\mathrm{IN}, 96^{\circ}\right.$ ) for $\mathrm{I} 6 \mathrm{~h}$., then neutralized; the freeze-dried supernatant accounted for $50 \%$ of the total cell wall. The $\mathrm{C}, \mathrm{H}, \mathrm{N}$ and $\mathrm{P}$ contents were $23 . \mathrm{I} \%, 4.02 \%, \mathrm{I} \cdot 93 \%$ and $0.88 \%$ respectively. The $\mathrm{P}$ amounted to $53 \%$ of the total wall content, and when combined with that of fraction I gave a recovery of about $84 \%$. Fraction 2 was completely soluble in cold water, and paper chromatography indicated the presence of glucose, laminaridextrins, galactose, mannose, $\mathrm{N}$-acetylglucosamine and glucosamine. The amino sugars were probably derived from chitin (see fraction 4) and, during the partial hydrolysis of the latter, deacetylation occurred. Acid hydrolysis produced glucose $(34.0 \%)$, galactose $(3.4 \%)$, galactosamine (trace) and mannose $(4.1 \%)$ and an uncharacterized mixture of amino acids. The collective data from fractions $I$ and 2 were equivalent to galactose and mannose recoveries of about $70 \%$ and $73 \%$ respectively. Assuming the majority of fraction 2 nitrogen to be protein, the protein content was calculated as $6 \cdot \mathrm{I} \%$, a recovery of about $68 \%$ of the total cell-wall protein. $\beta$-I, 3 Glucanase digestion of fraction 2 caused little depolymerization (about $3 \%$ ).

The i.r. spectrum of fraction 2 indicated the presence of an $\alpha-1,3$ glucan type polysaccharide (910 cm. ${ }^{-1}, 825 \mathrm{~cm}^{-1}$ ), a trace of a $\beta$-glucan (very weak absorbance at $\left.890 \mathrm{~cm}^{-1}\right)$ and a mannan $\left(870 \mathrm{~cm}^{-1}\right)$ (Fig. I).

Fraction 3. Fraction 3 comprised material from the second cold $2 \mathrm{~N}-\mathrm{NaOH}$ extraction and accounted for $13.8 \%$ of the total cell wall. This fraction lacked $\mathrm{P}$, and $\mathrm{C}, \mathrm{H}$ and $\mathrm{N}$ values were respectively $40.60 \%, 6.86 \%, 0.03 \%$. Solubility in cold water was slight and the only information derived from paper chromatography of the solubilized products was a reducing sugar reaction at the origin. The trace amount of nitrogen was not further identified. Glucose was released stoichiometrically from fraction 3 by mild acid hydrolysis $(3 \mathrm{~N}-\mathrm{HCl})$. Digestion by an exo- $\beta-\mathrm{I}, 3$ glucanase released glucose, laminaribiose, laminaritriose, laminaritetraose and two reducing sugars characteristic of gentiobiose, and a trisaccharide containing a $\beta$-I, 6 linkage (Chesters \& Bull, 1964, for method of analysis and identity) (see Fig. 2). The maximum hydrolysis of fraction 3 produced by this enzyme was just over $68 \%$ (reducing sugar: glucose, 1.03 ) and neither dialysis of the reaction mixture or replenishment of the enzyme induced further degradation. The elemental analysis of this fraction was in accord with its identity as a glucose polymer (theoretical values for a glucan are $\mathrm{C}$, $44.4 \% ; \mathrm{H}, 6.2 \%$ ). The collective data from fractions $\mathrm{I}, 2$ and 3 gave a glucose recovery of $94 \%$. The only notable feature of the i.r. spectrum was the strong shoulder at 890 to $880 \mathrm{~cm}^{-1}$ characteristic of the $\beta$-glucan (Fig. 3); this absorbance was not observed after $\beta$-I,3 glucanase digestion.

Fraction 4. This final fraction comprised a residue insoluble following the second alkali extraction and was equivalent to $12 \cdot 2 \%$ of the original wall material. The elemental composition $(\mathrm{C}, 43.5 \% ; \mathrm{H}, 7.10 \% ; \mathrm{N}, 5.67 \%$ ) was very similar to the theoretical analysis of chitin $(\mathrm{C}, 43.5 \% ; \mathrm{H}, 5.4 \% ; \mathrm{N}, 6.4 \%$, and when treated with a high purity chitinase from a Streptomyces species (Bull, I970a) chitobiose and $\mathrm{N}$-acetylglucosamine were released. Exhaustive incubation with this enzyme produced a maximum $80 \%$ hydrolysis; digestion of the comparable Neurospora crassa cell-wall fraction caused $73 \%$ solubilization. The $N$-acetylglucosamine plus glucosamine 


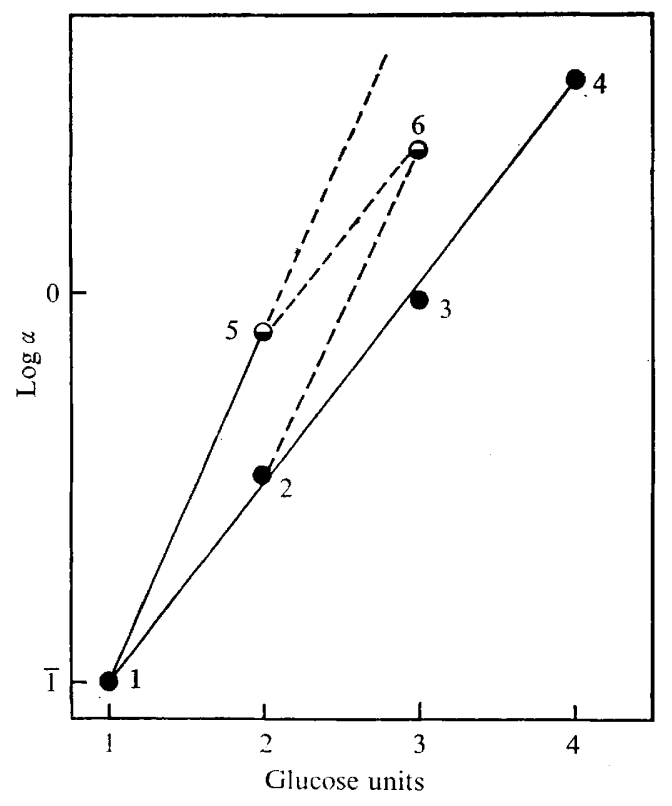

Fig. 2. Products of exo- $\beta-\mathrm{D}-\mathrm{I}, 3$ glucanase digestion of cell-wall fraction 3. I, Glucose; 2, laminaribiose; 3, laminaritriose; 4, laminaritetraose; 5, gentiobiose; 6, triglucoside $(\mathrm{Glcp} \beta \mathrm{I}-3 \mathrm{Glcp} \beta \mathrm{I}-6 \mathrm{Glc}) . \quad \alpha=\left(\mathrm{I}-R_{\mathrm{Glc}}\right) R_{\mathrm{Glc}}$, see Chesters \& Bull (1964). Solvent: butan-I-ol + pyridine + water $(6+4+3$, by vol.)

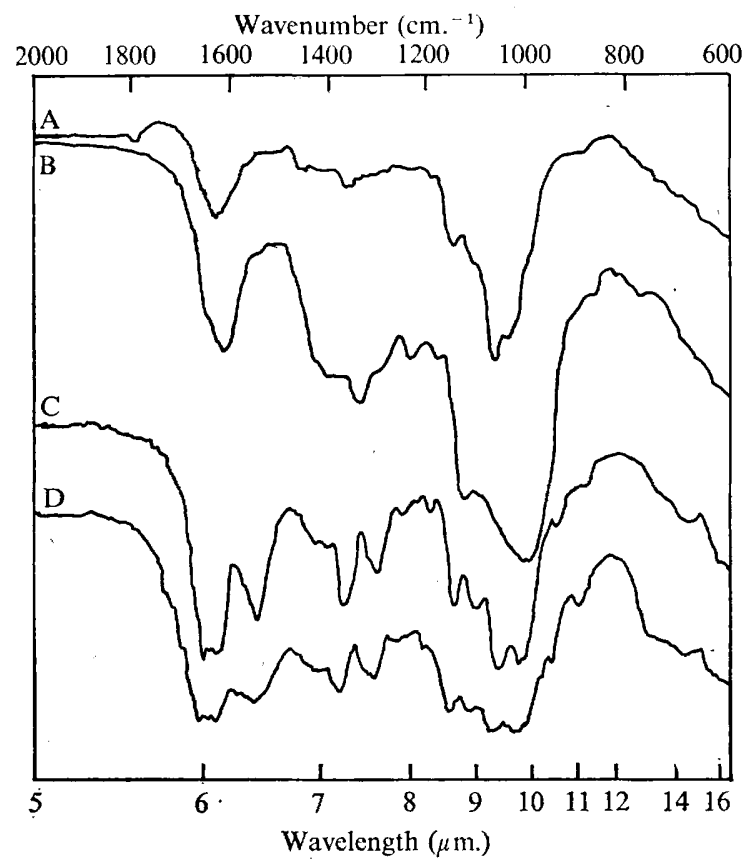

Fig. 3. Infrared spectra of Aspergillus nidulans cell walls: $\beta$-glycans. A, Laminaran. B, Cellwall fraction 3. C, Cell-wall fraction 4. D, Purified crustacean chitin. Tracings displaced vertically to facilitate comparison. 
content of the cell wall (see Table 2) agreed well with the amount of material recovered as fraction 4 . The identity of fraction 4 was confirmed by i.r. spectroscopy (Fig. 2).

Extraction of the wild-type I 3 cell wall by the Mahadevan \& Tatum procedure revealed that a significant amount of melanin remained associated with the chitin fraction. Conversely, when melanin was being extracted and purified, chitin was the most intractable polysaccharide in the cell wall and was present until the final stages of melanin preparation.

\section{The melanin pigment}

The preparation of melanin involved the complete removal of all extraneous cell wall materials by solvent and acid extractions. Nicolaus et al. (I964) found that such treatment did not produce major chemical changes in melanins although

Table 4. Elemental analyses of Aspergillus nidulans melanin: effect of growth conditions on composition

\begin{tabular}{|c|c|c|c|c|}
\hline \multirow[b]{2}{*}{ Strain } & \multirow[b]{2}{*}{ Conditions of melanin synthesis } & \multicolumn{3}{|c|}{ Percentage analysis } \\
\hline & & $\mathrm{C}$ & $\mathbf{H}$ & $\mathrm{N}$ \\
\hline I3 & Czapek-Dox medium* (batch culture) & $56 \cdot 40$ & $6 \cdot 55$ & 3.92 \\
\hline 13 & Czapek-Dox plus DOPA $\left(0.5 \mathrm{mg} . \mathrm{ml}^{-1}\right) \dagger$ & . & 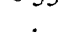 & 5.82 \\
\hline I3 & Czapek-Dox plus Catechol $\left(0.5 \mathrm{mg} . \mathrm{ml}^{-1}\right) \dagger$ & . & . & $I \cdot 78$ \\
\hline 224 & DAN $\ddagger$ (batch culture) & $44 \cdot 80$ & $5 \cdot 87$ & $4 \cdot 34$ \\
\hline 224 & DAN (chemostat culture, $\left.D=0.024 \mathrm{~h}^{-1}\right)$ & $59 \cdot 52$ & $6 \cdot 74$ & $3 \cdot 25$ \\
\hline . & Chemosynthetic DOPA-melanin & $48 \cdot 50$ & $4 \cdot 66$ & $6 \cdot 25$ \\
\hline . & DOPA-melanin, theoretical $\left(\mathrm{C}_{9} \mathrm{H}_{3} \mathrm{O}_{4} \mathrm{~N}\right)$ & $56 \cdot 00$ & 3.63 & $7 \cdot 26$ \\
\hline
\end{tabular}

partial decarboxylation and deamination probably occurred. The final product accounted for about 16 to I $8 \%$ of the Aspergillus nidulans wild-type cell wall. The pigment was insoluble in all non-polar solvents tested and in mineral acids; hot $\mathrm{NaOH}\left(0.5 \mathrm{~N}, 60^{\circ}, 24\right.$ h.) produced complete solubilization. Precipitation resulted when alkaline solutions were acidified to $\mathrm{pH} 2$ to 3 . The $A$. nidulans pigment had properties in common with other melanins: bleached by $\mathrm{H}_{2} \mathrm{O}_{2}(30 \%, \mathrm{v} / \mathrm{v})$; colour intensity reduced by glutathione and dithionate and restored on reoxidation; reduced ammoniacal $\mathrm{AgNO}_{3}$; produced characteristic blue-green ferrous sulphate-ferricyanide reaction; formed a flocculent iron-brown precipitate on addition of $\mathrm{FeCl}_{3}$ to an alkaline solution. That the pigment varied in composition with changing growth conditions is indicated by the data in Table 4 . The most significant finding was the widely varying $\mathrm{N}$ content of the melanin in response to the growth medium, especially when the latter was supplemented with $o$-dihydroxy phenols. Both $\mathrm{L}^{-}\left[{ }^{14} \mathrm{C}\right]$ tyrosine and DL-[carboxy- $\left.{ }^{14} \mathrm{C}\right] 3$ (3,4-dihydroxyphenyl)-alanine were incorporated into the cell-wall melanin and the extent of incorporation was dependent on the age of the culture at the time of feeding. Thus, when $\left[{ }^{14} \mathrm{C}\right]$ tyrosine and $\left[{ }^{14} \mathrm{C}\right] \mathrm{DOPA}$ were supplied to the culture at zero time, I9 \% and $28 \%$ of the label was incorporated into cell-wall melanin respectively; the incorporation was $43 \%$ and $69 \%$ when the precursors were fed to the culture after $30 \mathrm{~h}$., that is at the onset of declining growth rate. 
Attempts to characterize the Aspergillus nidulans melanin on the basis of its degradation products were only partially successful. The pigment (I00 mg.) was oxidized by $37.8 \mathrm{ml}$. $\mathrm{KMnO}_{4}(3 \%$, w/v) but ether extraction of the solution did not reveal any identifiable products. In contrast, alkali fusion of the melanin (100 mg.) with $\mathrm{NaOH}\left(300 \mathrm{mg}\right.$.) and sodium dithionite $\left(50 \mathrm{mg}\right.$.) at $300^{\circ}$ for $10 \mathrm{~min}$. produced

Table 5. Degradation products from the alkali fusion of Aspergillus nidulans melanin

Tentative identity

5,6-Dihydroxyindole-2- $\mathrm{COOH}$

Indole-2- $\mathrm{COOH} \S$

5-Hydroxyindole $\$$

Pyrrole-2- $\mathrm{COOH}$

Pyrrole-3-COOH§

Pyrrole-2,4- $\mathrm{COOH}$, or pyrrole-2,5-

$\mathrm{COOH}$

3,4-Dihydroxybenzoic acid

\begin{tabular}{|c|c|}
\hline \multicolumn{2}{|c|}{ Chromatography } \\
\hline$R_{\mathrm{F}^{\prime}}(\mathrm{BAW})^{*}$ & $R_{\mathrm{F}}(\mathrm{PAW}) \dagger$ \\
\hline 0.57 & . \\
\hline 0.93 & . \\
\hline 0.90 & \\
\hline 0.87 & 0.76 \\
\hline 0.84 & 0.49 \\
\hline & 0.27 \\
\hline
\end{tabular}

+ Present.

* Butan-I-ol + acetic acid + water $(60+I 5+25, \mathrm{v} / \mathrm{v})$.

$\dagger$ Propan-I-ol + ammonia + water $(60+30+10, v / v)$.

$\ddagger$ Pyridine + acetate, $\mathrm{pH} 6 \cdot \mathrm{I}$.

$\S$ Spots of strongest intensity indicated.

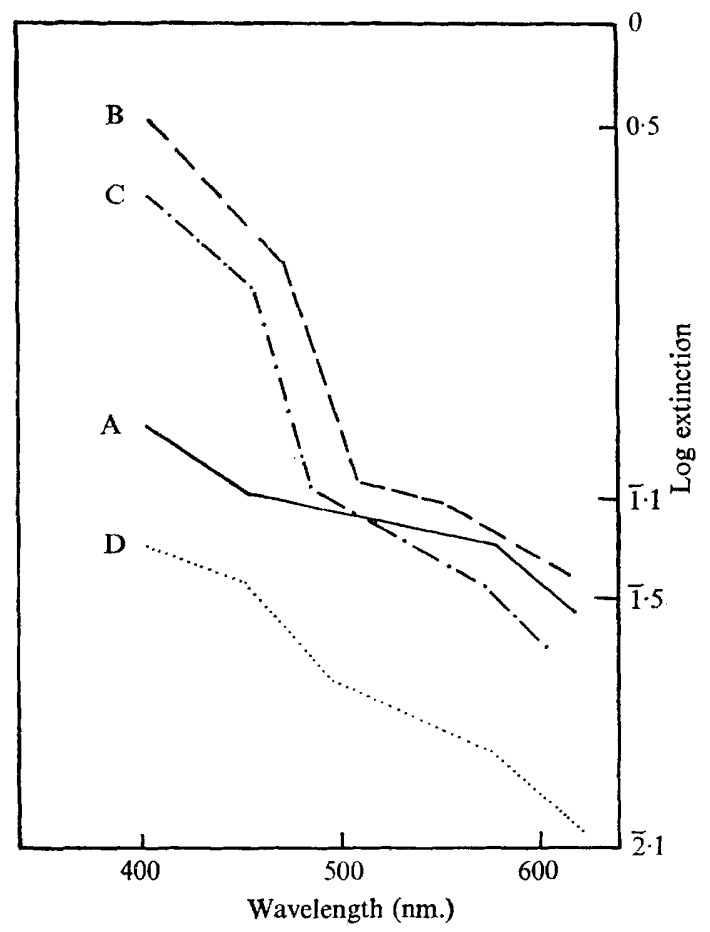

Fig. 4. Extinction of wild-type and mutant Aspergillus nidulans melanins. A, Wild-type I3 melanin. B, Purple mutant I3y.ma alkali-extracted pigment. C, Purple mutant 13y.ma $\times$ pink mutant I3y.pi alkali-extracted hybrid pigment. D, Chemisynthesized DOPA-melanin. Mutants I 3y. ma and I 3y.pi are described by Bull \& Faulkner (1965). 
$23.8 \%$ degradation; degradation of the chemisynthesized DOPA-melanin by similar treatment was $28.6 \%$. Of the I8 ether-extractable degradation products from the fungal melanin, half were identified tentatively (see Table 5) on the basis of cochromatography and co-electrophoresis, colour reactions with ethanolic $3 \% \mathrm{FeCl}_{3}$, diazotized sulphanilic acid and Ehrlich's reagent, and response to u.v. light. The chromatographic mobilities of authentic samples and published values (Nicolaus et al. 1964) often differed by as much as one or more $R_{F}$ units.

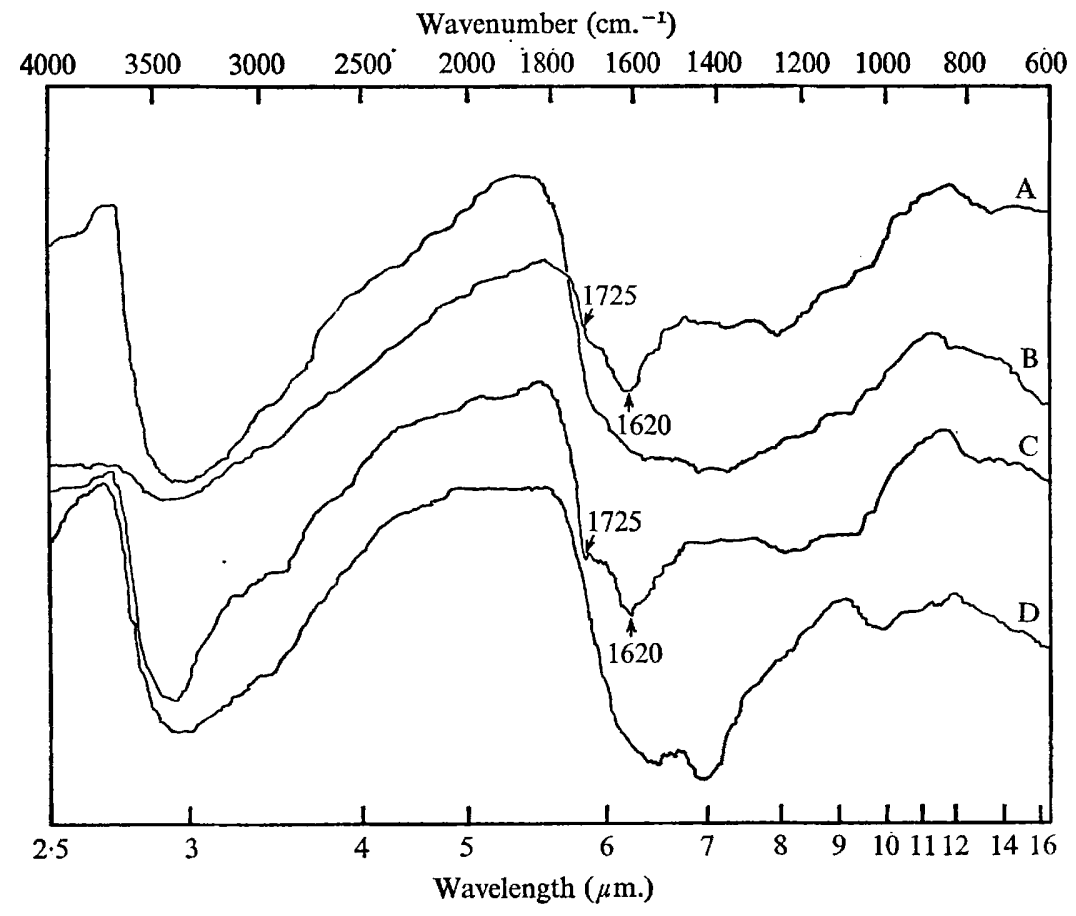

Fig. 5. Infrared spectra of native and synthetic melanins. A, Wild-type Aspergillus nidulans I3 melanin. B, As A but extracted with $0.5 \mathrm{~N}-\mathrm{NaOH}$. C, Chemisynthesized DOPA-melanin. $\mathrm{D}$, As $\mathrm{C}$ but extracted with $0.5 \mathrm{~N}-\mathrm{NaOH}$. Tracings displaced vertically to facilitate comparison.

Logarithmic plots of absorbance in the visible range for the wild-type melanin and melanoid pigments from previously described mutants (Bull \& Faulkner, I964; 1965) produced a series of straight lines as shown in Fig. 4. The i.r. spectrum of the wild-type melanin was very similar to that of DOPA-melanin. Neither spectrum had features of significant diagnostic value but the absorbances at 1620 and $1725 \mathrm{~cm} .^{-1}$ gave some indication of carboxyl groups. The latter absorbances disappeared after brief treatment of the pigments with dilute $\mathrm{NaOH}$ (Fig. 5).

Finally, the homogeneity of various samples of the Aspergillus nidulans melanin was investigated by gel filtration on a Sephadex G-200 column previously calibrated for molecular size determination. All samples were separable into a series of fractions having different molecular sizes equal to or greater than $2 \times 10^{6}$ (Fig. 6). Recovery of the melanin from this column was high in all experiments when based upon the extinction at $540 \mathrm{~nm}$. The elution pattern of extracted melanins was composed of three commonly positioned peaks $\left(\mathrm{P}_{1}, \mathrm{P}_{2} b, \mathrm{P}_{4}\right)$ and other minor peaks $\left(\mathbf{P}_{2}, \mathbf{P}_{3} a, \mathbf{P}_{3} b\right)$ 


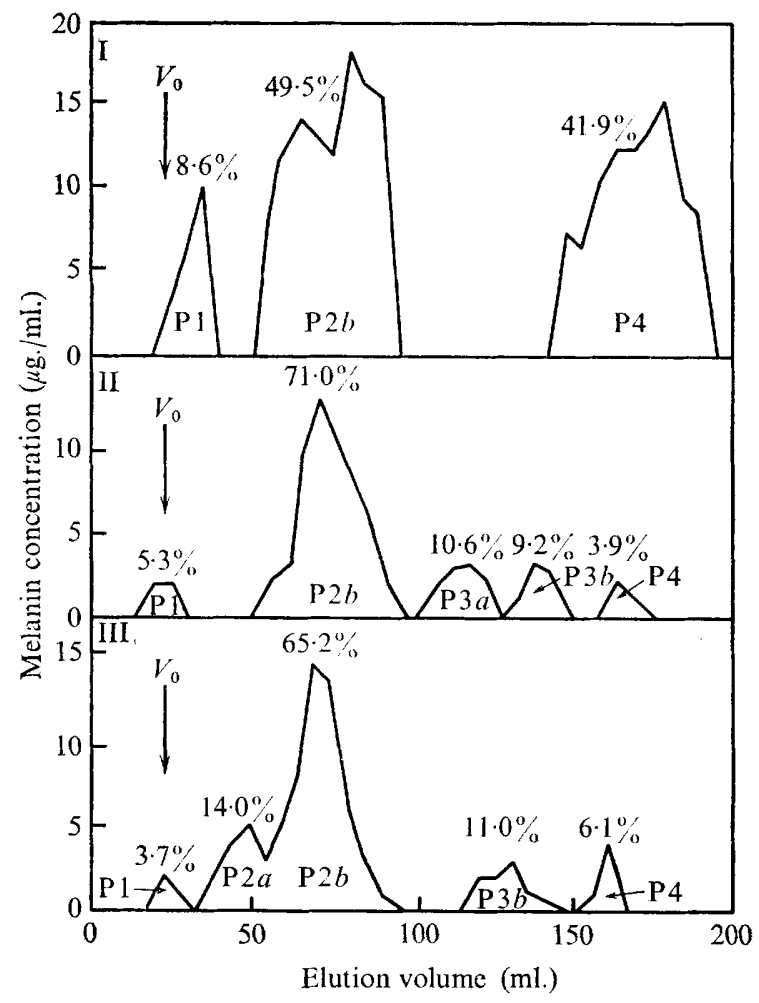

Fig. 6. Fractionation of Aspergillus nidulans melanins on Sephadex G-200 gel. I, Cell-wall melanin produced in unsupplemented cultures. II, Cell-wall melanin produced in $\mathrm{L}-\left[{ }^{14} \mathrm{C}\right]-$ tyrosine cultures. III, Cell-wall melanin produced in DL-[carboxy- $\left.{ }^{14} \mathrm{C}\right] \mathrm{DOPA}$ cultures. Column size: $255 \times 20 \mathrm{~mm}$.; $V_{0}$ (void volume) measured with Dextran Blue (M.W. $=2 \cdot 0 \times$ $\mathrm{ro}^{6}$ ). Elution with $\mathrm{I} \mathrm{M}-\mathrm{NaCl}$ at $10^{\circ}$ in the dark. Fractions ( $10 \mathrm{ml}$.) collected automatically and melanin assayed spectroscopically. Recovery of melanin applied to the column: I $(82.1 \%)$; II $(88 \cdot 0 \%)$; III $(100 \cdot 0 \%)$.

Table 6. Molecular size and specific activity of melanin fractions

\begin{tabular}{|c|c|c|c|c|c|}
\hline \multirow[b]{3}{*}{ Peak* } & \multicolumn{5}{|c|}{ Melanin sample $\dagger$} \\
\hline & \multirow{3}{*}{$\begin{array}{c}\text { I: Unsupplemented } \\
\text { (mol. size }+) \\
\geqslant 2 \cdot 0 \times 10^{6}\end{array}$} & \multicolumn{2}{|c|}{ II: $\left[{ }^{[4} \mathrm{C}\right]$ tyrosine } & \multicolumn{2}{|c|}{ III: $\left[{ }^{14} \mathrm{C}\right] \mathrm{DOPA}$} \\
\hline & & Mol. size & Sp.act.§ & Mol. size & Sp.act. \\
\hline P I & & $\geqslant 2.0 \times 10^{6}$ & I $6 I$ & $\geqslant 2.0 \times 10^{6}$ & 240 \\
\hline P $2 a$ & . & . & . & $6.6 \times 10^{5}$ & 53 \\
\hline $\mathbf{P}_{2} b$ & $3 \cdot 3 \times 10^{5}$ & $3.2 \times 10^{5}$ & 494 & $3.8 \times 10^{5}$ & 1278 \\
\hline $\mathrm{P}_{3} a$ & . & $4.7 \times 10^{4}$ & 80 & . & . \\
\hline $\mathrm{P}_{3} b$ & . & $1.0 \times 10^{4}$ & 39 & $1 \cdot 3 \times 10^{4}$ & 104 \\
\hline $\mathrm{P}_{4}$ & $2.7 \times 10^{3}$ & $3.1 \times 10^{3}$ & I9I & $2.7 \times 10^{3}$ & 56 \\
\hline
\end{tabular}

* See Fig. 5 .

$\uparrow$ Melanins extracted from wild-type Aspergillus nidulans 13 . Growth in: I, defined medium (DAN); II and III, DAN supplemented with $\mathrm{L}-\left[{ }^{14} \mathrm{C}\right]$ tyrosine and $\mathrm{DL}-\left[{ }^{[4} \mathrm{C}\right] \mathrm{DOPA}$ during the declining growth rate phase.

\$ Molecular size estimated by gel filtration on Sephadex G-200.

$\$ \mathrm{~m} \mu \mathrm{Ci} \mathrm{mg.}{ }^{-1}$ 
characterized the tyrosine- and DOPA-labelled melanins. Also, the data in Table 6 indicate that the specific activity of the ${ }^{14} \mathrm{C}$-labelled melanin fractions varied markedly and was not related in a simple way to molecular size.

\section{DISCUSSION}

The hyphal walls of Aspergillus nidulans comprised largely polysaccharide with minor amounts of lipid and protein and, in the case of the pigmented wild-type strain, melanin. The high glucan plus chitin content of the $A$. nidulans cell wall ( 60 to $64 \%$ ) is typical of Ascomycetes, as is also the presence of galactose and galactosamine. Mannose also is a usual component of Asomycete cell walls (see BartnickiGarcia, I968, for a critical review). Until recently, the evidence for uronic acids in fungal cell walls has been disputed, but the mild hydrolysis and separation procedures recommended by Gancedo et al. (1968) have enabled this question to be resolved. Application of these methods to $A$. nidulans revealed the presence of approximately I to $3 \%$ of glucuronic acid in its cell wall, a value of the same order as reported for Alternaria, Fusarium and Penicillium (Gancedo et al. 1968). It must be stressed that the percentage composition data presented in this paper are not absolute and can be expected to vary significantly with the conditions of culture of the fungus. Moreover, the data on the recovery of various components are subject to the limitations of the extraction techniques used. For example, $\beta-\mathrm{I}, 3$ glucans are susceptible to degradation by $\beta$-alkoxyl elimination and hence the value of $13.8 \%$ obtained for the $\beta$-glucan (fraction 3) was probably a serious underestimate; this interpretation seems warranted by the detection of laminaridextrins in cell-wall fractions $x$ and 2 . The low recovery (about $68 \%$ ) of protein from fractionated cell walls was because it was partially extracted with lauryl sulphate during the initial stage of the Mahadaven \& Tatum (1965) fractionation procedure. Indeed, the present investigation has demonstrated the efficacy of detergent extraction for measuring cell-wall protein, especially when the conventional, direct methods such as biuret are subject to interference by materials such as melanin.

Chemical fractionation studies of Aspergillus nidulans cell walls allowed a number of conclusions to be made on their polymer composition. There appeared to be at least two alkali-soluble glucans, one of which, the $\beta$-glucan, was released only after the acid extraction, whilst the $\alpha$-glucan was solubilized by the initial alkali treatment. The infrared spectral analyses of the $\alpha$-glucan indicated its close relation to the $\alpha-\mathrm{I}, 3$ glucan of Cryptococcus cell walls reported by Bacon et al. (I 968) and distinguished it clearly from the mixed linkage $\alpha$-glucan nigeran. Furthermore, the release of reducing sugars from fraction $I$ and attributable to mycodextranase action amounted to only a very small portion of the total glucose present. The $A$. nidulans $\alpha$-glucan resembled other strongly dextrorotatory fungal glucans in not giving a colour reaction with iodine (Gorin \& Spencer, I968); moreover, it was not attacked by amylases. The $\beta$-glucan, which was partially destroyed during acid and alkali extraction, was of a non-cellulosic type as demonstrated by its susceptibility to exoand endo- $\beta-\mathrm{I}, 3$ glucanase hydrolysis and the lack of complex formation with Schweizer's reagent. On the basis of its insolubility in cuprammonium hydroxide and paper chromatography of enzyme hydrolysates, it was concluded that the $\beta$-glucan contained a preponderance of $\beta$-I,3 glucosidic linkages and a smaller 
proportion of $\beta$-I,6 linkages. The $68 \%$ limit to hydrolysis by exo- $\beta$-I, 3 glucanase suggested that the $\beta$-glucan might have a 'block-type' structure in which a number of say -I,6 linkages are surrounded by $-\mathrm{I}, 3$ linkages.

Aspergillus nidulans cell walls contained two hexosamine polymers: chitin and one composed of, or containing, galactosamine. The galactosamine polymer was largely extracted as fraction $\mathrm{I}$ by $2 \mathrm{~N}-\mathrm{NaOH}$ whereas the chitin remained resistant to alkali and acid treatments; the two hexosamines are therefore components of different polymers. The $N$-acetylglucosamine to galactosamine ratio in the wall of the albino mutant was $\mathrm{I} \cdot 32$, a value similar to that found in the walls of Helminthosporium sativum (Applegarth \& Bozoian, 1969). Much smaller galactosamine contents have been reported for other fungal cell walls, including a different strain of $A$. nidulans (Mahadevan \& Tatum, I965; Cohen, Katz \& Rosenberger, I969).

The polymers containing galactose, mannose, amino and glucuronic acids were not characterized. Most of the cell-wall mannose was found in fraction 2, and i.r. spectroscopy suggested the presence of a glucommanan. Galactose was extracted in almost equal proportions by cold alkali and acid (fractions I and 2). Protein was associated with fraction 2. Emiliani \& Ucha de Davie (1962) claimed that such components were found as glucomannoprotein and galactomannoprotein complexes in Aspergillus phoenicis, while an alkali insoluble glucomannogalactan has been proposed as an entity in an unidentified Aspergillus species (Ruiz-Herrera, 1967).

The presence of melanin in the wild-type cell wall is clearly responsible for its resistance to lytic enzymes (Bull, I970a). However, the respective limit hydrolyses of the $\beta$-glucan $(68 \%$ ) and chitin $(80 \%)$, which represented 6 to $7 \%$ of the cell wall not degraded, suggest that factors other than melanin may be involved in the prevention of total cell wall dissolution. Previously I have found (Bull, I970a) that a resistant 'core' of chitin and $\alpha$-glucan persisted after enzymic lysis of Aspergillus nidulans cell walls.

Histochemical data and evidence from enzymolysis experiments indicated that the melanin was located throughout the thickness of the wall and, probably, formed an especially intractable complex with chitin (Bull, I970a). In gel filtration experiments of Aspergillus nidulans melanin preparations, all melanin samples analysed possessed three common peaks, corresponding to molecular weights of approximately $2,000,000$, 350,000 and 2900 . These data suggest that the melanin is a finite heteropolymer whose component molecules differ in molecular size, in contrast to an infinite homopolymer whose size is limited merely by the amount of available precursors. This size distribution of melanin may reflect a location of pigment molecules of specific molecular dimensions in different parts of the cell wall. Brown, Falkehag \& Cowling (1967) favoured a similar explanation for the macromolecular structure of lignin in sweetgum wood.

On the basis of the degradation studies, the Aspergillus nidulans melanin appears to be, at least in part, indolic in nature. A number of degradation products have been tentatively identified but further interpretation of these results must be cautioned on the grounds of artefact production during melanin extraction: (I) strong acid treatment of the cell wall may have caused acid-catalysed rearrangements in the quinonoid structure; (2) the degradation products (note their low yields) may have been differentially susceptible to further decomposition by alkali fusion. Hence the relative intensities of products noted in Table 5 are not necessarily significant in any 
definition of the melanin structure. Visible spectra of the pink and purple mutants' pigments invariably had broad extinction maxima at 520 to $550 \mathrm{~nm}$. and, less frequently, a sharper extinction at $480 \mathrm{~nm}$. These extinctions closely correspond to those of melanochromes and dopachrome (Bu'Lock, I960) and add further support to the characterization of the $A$. nidulans melanin as indolic.

Few detailed analyses of fungal melanins are available with which to compare those from Aspergillus nidulans. Potgieter (1965) quotes elemental analyses of melanins extracted from Rhizoctonia solani $(\mathrm{C}, 62.0 ; \mathrm{H}, 4.8 ; \mathrm{N}, 3.3 \%$ ) and Cladosporium herbarum $(\mathrm{C}, 60 \cdot 7 ; \mathrm{H}, 4.0 ; \mathrm{N}, 2.2 \%$ ) which are very similar to those of $A$. nidulans. Further information on the Rhizoctonia and Cladosporium pigments is not available, consequently reference of the nitrogen content to indolic residues cannot be made. Nicolaus et al. (1964), however, concluded that the melanins of Ustilago maydis spores and Capnodium nerii hyphae are non-indolic, the melanin from the former species being catecholic in composition.

During the present investigations, carboxyl groups were indicated in the Aspergillus nidulans melanin by i.r. spectroscopy and by the incorporation of [carboxy $\left.-{ }^{14} \mathrm{C}\right] \mathrm{DOPA}$ into the pigment. Carboxyl groups in the fungal pigment were titrated against $0.2 \mathrm{~N}-\mathrm{Na}_{2} \mathrm{CO}_{3}$ by the method of Piattelli \& Nicolaus (I96I) (A. T. Bull, unpublished experiments). A titration difference $(0.2 \mathrm{~N}-\mathrm{HCl})$ of $133.3 \mathrm{ml}$. g. ${ }^{-1}$ was observed for melanin synthesized in unsupplemented media (Table 4 , first entry), while a chemisynthetic DOPA-melanin had a corresponding value of $99 \cdot 2 \mathrm{ml} . \mathrm{g} \cdot{ }^{-1}$. The origin of these carboxyl groups is open to doubt; they may reflect incorporation of DOPA itself into the melanin molecule, or may be derived from oxidative decomposition of quinones during the synthesis of melanin. The question of whether melanin is a chemically homogeneous polymer (single type of subunit and linkage group) or heterogeneous polymer (multiple types of subunit and bondings) also has been debated (see Mason, 1966). The data reported in this paper on the elemental composition of the pigment synthesized under different growth conditions and on the specific activities of $\left[{ }^{14} \mathrm{C}\right]$ melanin fractions offer some support for the heterogeneous view of melanins.

I wish to thank Dr Martin Alexander for the hospitality extended to me at Cornell University, and Mr Gary Oatman for his excellent technical assistance. The investigation was supported by U.S. Public Health Service Grant no. UI oo 20 from the National Centre for Urban and Industrial Development; and by a grant from the Science Research Council (U.K.) for the melanin studies. I am grateful to the U.S.U.K. Educational Commission for the award of a Fulbright Travel Grant.

\section{REFERENCES}

Applegarth, D. A. \& Bozolan, G. (1969). The cell wall of Helminthosporium sativum. Archives of Biochemistry and Biophysics 134, 285-289.

Bacon, J. S. D., Jones, D., FArmer, V. C. \& Welbey, D. M. (I968). The occurrence of $\alpha-(I-3)$ glucan in Cryptococcus, Schizosaccharomyces and Polyporus species and its hydrolysis by a Streptomyces culture filtrate lysing cell walls of Cryptococcus. Biochemica et Biophysica Acta 158, 313-3I5.

Barker, S. A., Bourne, E. J., Stacey, M. \& Whiffen, D. H. (1954). Infrared spectra of carbohydrates. I. Some derivatives of D-glucopyranose. Journal of the Chemical Society, London, pp. I7I-I76. 
BARTNICKI-Garcia, S. (1966). Chemistry of hyphal walls of Phytophthora. Journal of General Microbiology 42, 57-69.

Bartnicki-Garcia, S. (1968). Cell wall chemistry, morphogenesis and taxonomy of fungi. Annual Review of Microbiology 22, 87-108.

Bartnicki-Garcia, S. \& Nickerson, W. J. (1962). Isolation, composition and structure of cell walls of filamentous and yeast-like forms of Mucor rouxii. Biochemica et Biophysica Acta 58, 102I19.

Bloomfield, B. \& Alexander, M. (1967). Melanins and resistance of fungi to lysis. Journal of Bacteriology 93, 1276-1280.

BremNer, J. M. (I960). Determination of nitrogen in soil by the Kjeldahl method. Journal of Agricultural Science 55, I I-19.

Brown, W., Falkehag, S. I. \& Cowling, E. B. (1967). Molecular size distribution of lignin in wood. Nature, London 214, 410-4I I.

Bull, A. T. (1962). $R_{\mathrm{G}}$ values of laminaridextrins, mannitol-containing laminaridextrins and various products of trans- $\beta$-glucosylation. Journal of Chromatography $7, \mathrm{D}_{23}$.

Bull, A. T. (1968). Liquid scintillation counting techniques for the radioassay of $\left[{ }^{14} \mathrm{C}\right] \mathrm{melanin}$. Journal of Labelled Compounds 4, 181-I91.

Bull, A. T. $(\mathrm{I} 970 \mathrm{a})$. Inhibition of polysaccharases by melanin. Enzyme inhibition in relation to mycolysis. Archives of Biochemistry and Biophysics r37, 345-356.

Bull, A. T. (1970 $b$ ). Kinetics of cellulase inactivation by melanin. Enzymologia (in the Press).

Bull, A. T. \& Faulkner, B. M. (1964). Physiological and genetic effects of 8-azaguanine on Aspergillus nidulans. Nature, London 203, 506.

Bull, A. T. \& Faulkner, B. M. (1965). Melanin synthesis in wild-type and mutant strains of Aspergillus nidulans. Journal of General Microbiology 4r, iv.

Bu'LocK, J. D. (1960). Intermediates in melanin formation. Archives of Biochemistry and Biophysics 9r, I89-193.

CARTER, B. L. A. \& Bull, A. T. (I969). Studies of fungal growth and intermediary carbon metabolism under steady and non-steady state conditions. Biotechnology and Bioengineering Ir, 785-804.

Chesters, C. G. C. \& Bull, A. T. (1964). Transglucosylase activity of fungal laminarinases. Nature, London 202, 454-456.

Cohen, J., KATZ, D. \& Rosenberger, R. F. (1969). Temperature sensitive mutant of Aspergillus nidulans lacking amino sugars in its cell wall. Nature, London 224, 713-7I 5 .

Dryer, R. L., TAmmes, A. E. \& Roth, J. I. (1957). Determination of phosphorus in body fluids. Journal of Biological Chemistry 225, I77-183.

Emiliani, E. \& UCHA DE DAVIE, I. (I962). Induced autolysis of Aspergillus phoenicis (A. niger group). IV. Carbohydrates. Applied Microbiology ro, 504-51 2.

Gancedo, J. M., Gancedo, C. \& Asensio, C. (I968). Uronic acids in fungal cell walls. Biochemische Zeitschrift 346, 328-332.

Gorin, P. A. J. \& Spencer, J. F. T. (I968). Structural chemistry of fungal polysaccharides. Advances in Carbohydrate Chemistry 23, 367-417.

Jayme, G. \& LANG, F. (I963). Cellulose Solvents. In Methods in Carbohydrate Chemistry, vol. III, p. 75. Edited by R. L. Whistler \& M. L. Wolfrom. New York: Academic Press.

Kuo, M.-J. \& Al.EXANDER, M. (1967). Inhibition of the lysis of fungi by melanins. Journal of Bacteriology $94,624-629$.

LoEwUS, F. A. (I952). Improvement in the anthrone method for determination of carbohydrates. Analytical Chemistry 24, 219.

Lowry, O. H., Rosebrough, N. J., Farr, A. L. \& Randall, R. J. (I95I). Protein measurement with the Folin phenol reagent. Journal of Biological Chemistry 193, 265-275.

Mahadevan, P. R. \& TAtum, E. L. (1965). Relationship of the major constituents of the Neurospora crassa cell wall to wild-type and colonial morphology. Journal of Bacteriology 90, 1073-1081.

Marchessault, R. H. (1962). Application of infrared spectroscopy to cellulose and wood polysaccharides. Pure and Applied Chemistry 5, 107.

Mason, H. S. (1966). The structure of melanin. In The Pigmentory System. Advances in the Biology of Skin, vol. VII, p. 293. Edited by S. Fox. Oxford: Pergamon Press.

Mitchell, A. J. \& SCURfield, G. (1967). Composition of extracted fungal cell walls as indicated by infrared spectroscopy. Archives of Biochemistry and Biophysics 120, 628-637. 
NeLson, N. (1944). A photometric adaptation of the Somogyi method for the determination of glucose. Journal of Biological Chemistry 153, 375-380.

Nicolaus, R. A., Piattelli, M. \& Fattorusso, E. (1964). The structure of melanins and melanogenesis. IV. On some natural melanins. Tetrahedron 20, I I63-1 172.

Pearson, F. G., Marchessault, R. H. \& Liang, C. Y. (1960). Infrared spectra of crystalline polysaccharides. V. Chitin. Journal of Polymer Science 43, IOI-I I6.

Piattelli, M. \& Nicolaus, R. A. (196I). The structure of melanins and melanogenesis. I. The structure of melanin in Sepia. Tetrahedron 15, 66-75.

PotgiETER, H. G. (1965). Susceptibility and Resistance of Fungi to Microbial Lysis. Ph.D. Thesis, Cornell University.

Potgieter, H. G. \& AleXANDer, M. (1966). Susceptibility and resistance of several fungi to microbial lysis. Journal of Bacteriology 91, I526-1532.

Reissig, J. L., Strominger, J. L. \& Leloir, L. F. (I955). A modified colorimetric method for the estimation of $N$-acetylamino sugars. Journal of Biological Chemistry 217, 959-966.

Ruiz-Herrera, J. (1967). Chemical composition of the cell wall of an Aspergillus species. Archives of Biochemistry and Biophysics 122, II 8-125.

Somogyi, M. (1952). Notes on sugar determination. Journal of Biological Chemistry 195, 19-23.

STOFFYN, P. J. \& JEANLOZ, R. W. (1954). Identification of amino sugars by paper chromatography. Archives of Biochemistry and Biophysics 52, 373-379.

TunG, K. K. \& Nordin, J. H. (1967). Evidence for a buried location of nigeran in the cell wall of Aspergillus niger. Biochemical and Biophysical Research Communications 28, 519-524.

vaN Soest, P. J. (1963). Use of detergents in the analysis of fibrous feeds. I. Preparation of fibre residues of low nitrogen content. Journal of the Association of Official Agricultural Chemists $46,825-829$.

WANG, S. L. (1964). Microbial Lysis of Soil Fungi. M.S. Thesis, Cornell University. 